
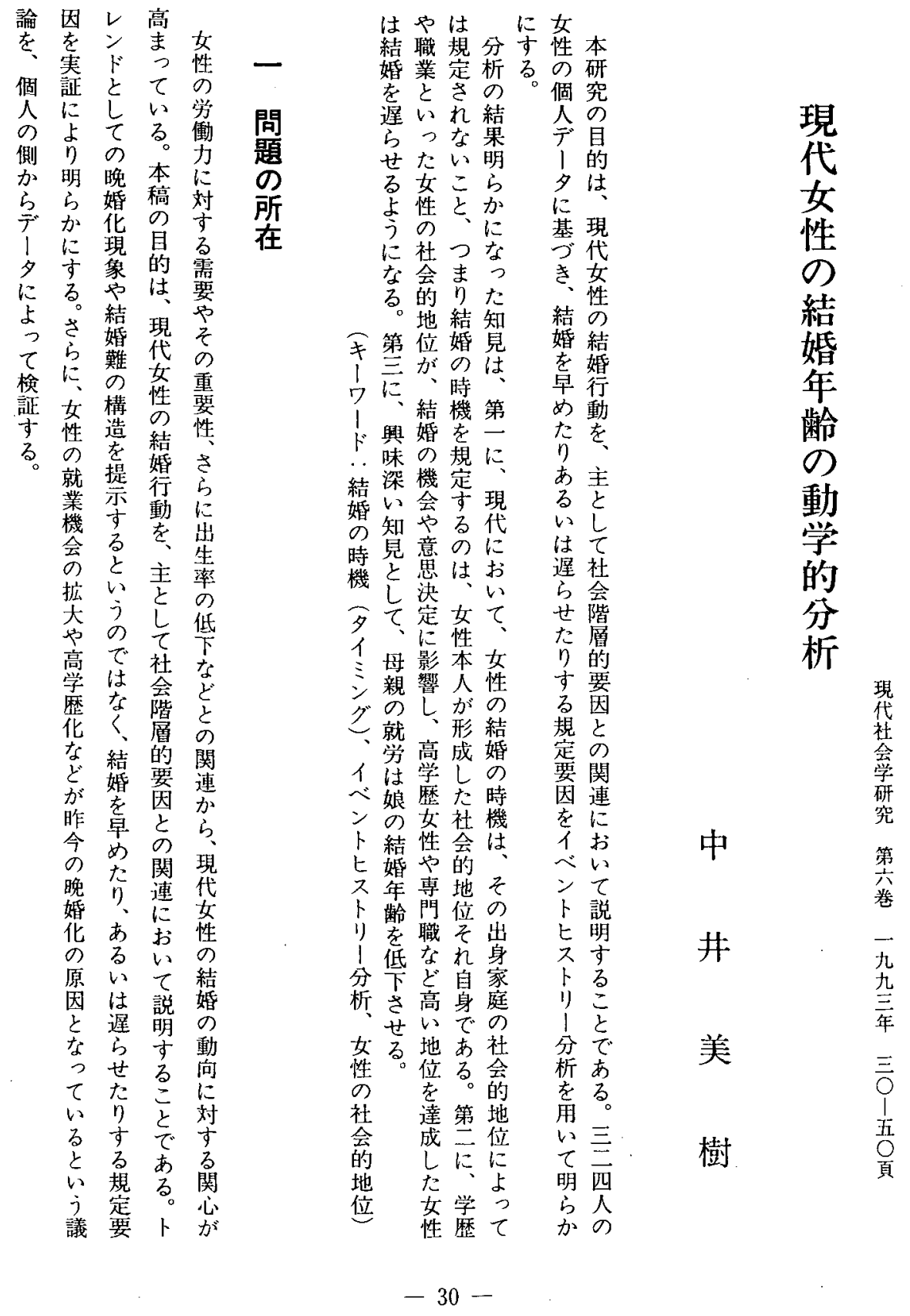


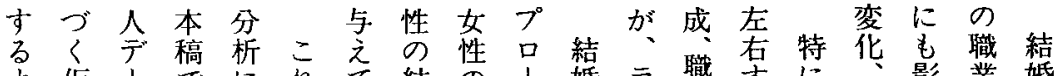

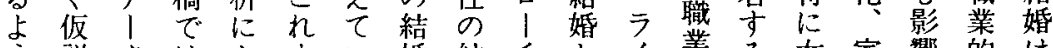

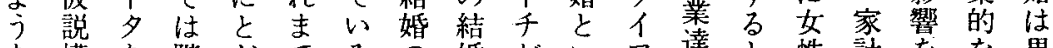
な構を階どでるの婚がいつ達と性計をな男 動築用層ま結の夕年存う不成いに内与キ性

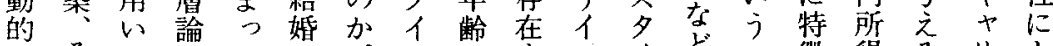

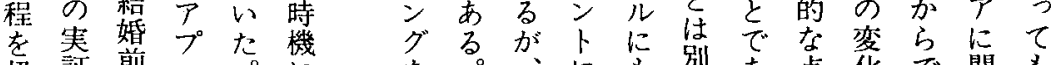

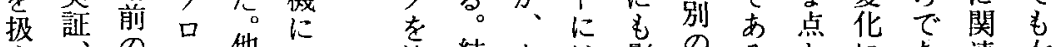
う。個!他方決結なは影のるるとにあ連女

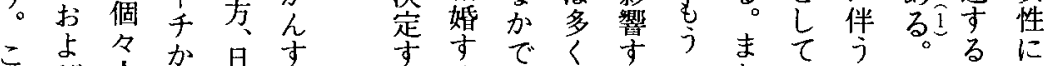

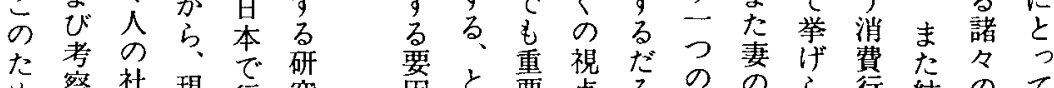

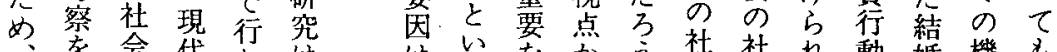

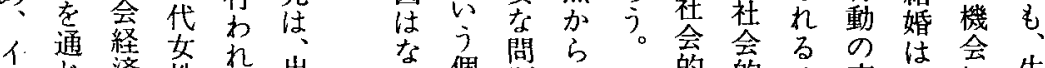

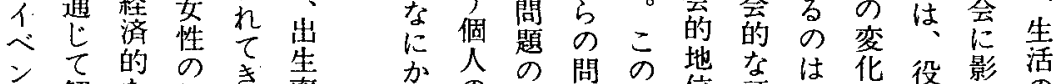
卜解な結た率㔔のの閶よ垃評は化役影活

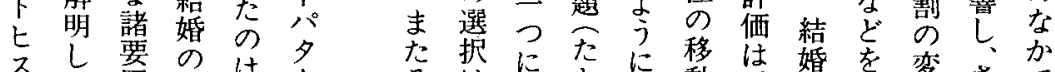

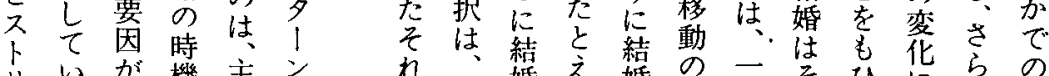

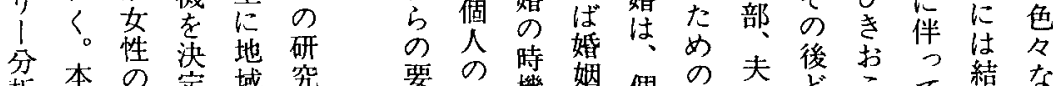

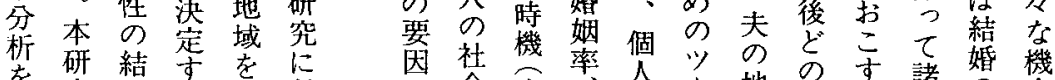
究婚方単付 は会多率人产地の市諸婚機 用での階位随 女階イ結の儿位占。機時に

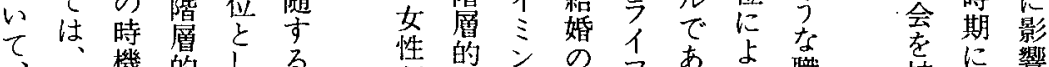
結結を機的じる 要だ

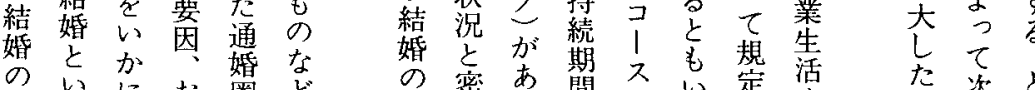

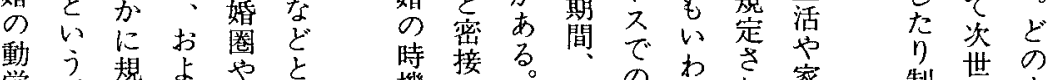
学、替 よ や

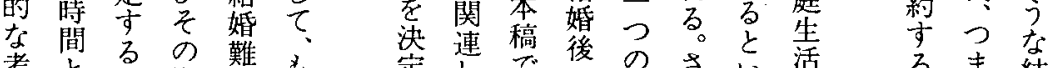

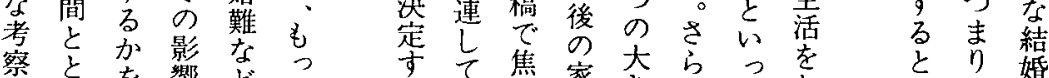

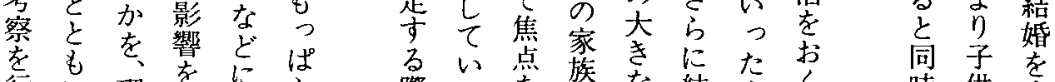

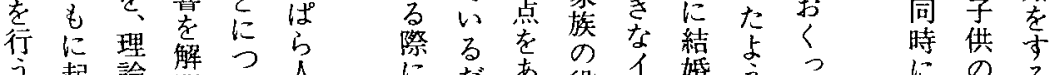

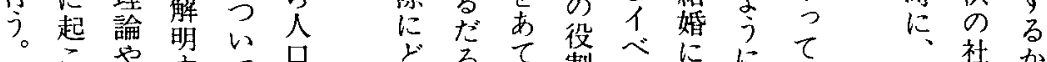

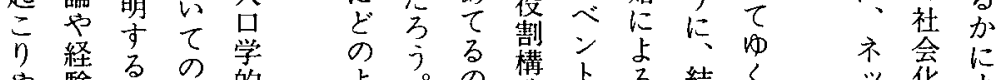

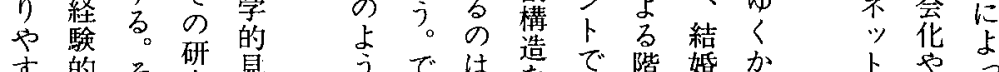
す的そ研見方では造で階婚か

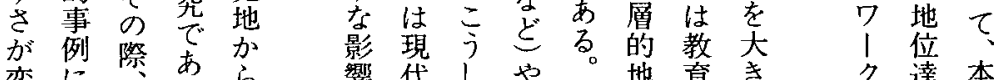

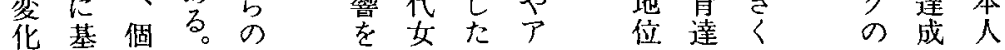




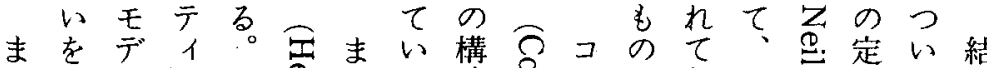
た示ルこそすたる造过にに西苛式て婚

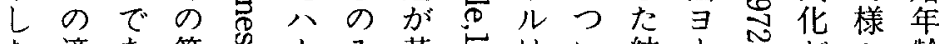

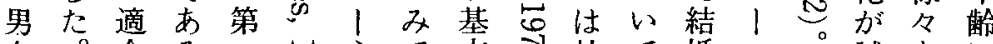
女。合る一品亦で本き社て婚口乞試なに

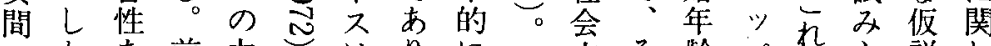

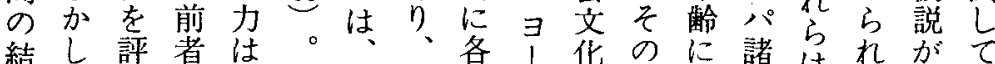

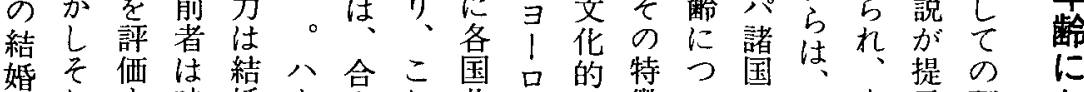

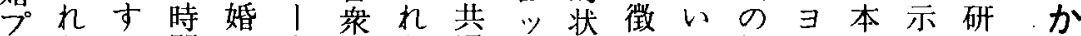
口らる間へ木国ら通，ハ況やて結|格さ究 セのととのスのので諸の問の婚口的れは 差とと社は七パあ詯異題研年ッな妵す

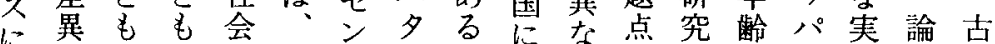
こをにに的人サ1こつるをのパ諸証しく先 い生男なは強なンとい諸明う夕国にらは てじ男まプ結デにをて集らち、に結れ

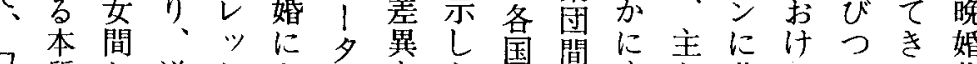
コ質お逆シかををたすのですと共るいた化 儿的よにさん利生し既、る。通出た。近す マ要人後で、しるか婚結 ン因種者あ二!、根し曲怒 はの間はりう初本な線年 結解の時、の婚的が等齢 婚明比間第力婚なら年秢

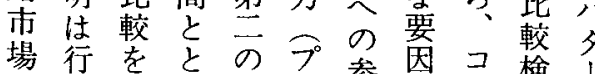
のわ行毛力レ参老了険!

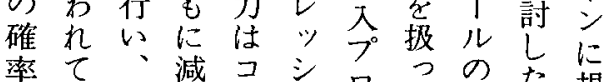
的い性少木ャ寺七研結賛

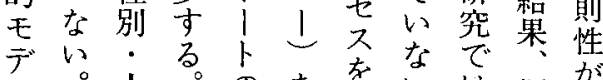
ル。人。のを表いは標が を種以成受表。も準存 構蕳志貝け数方的在

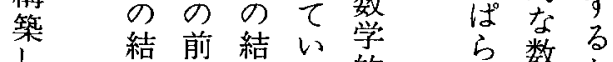
乙 婚提 婚る的各学加

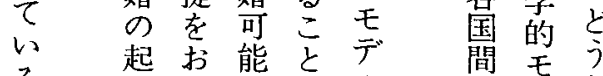
るこい性をル比声か

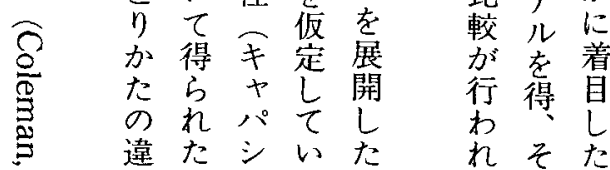
が率の年な 個発のとはわ 人見歴な、ち 個さ史つ初平 人㣗的て婚均 がたなき参初 結こ低た入婚 婚と下 $7^{\circ}$ 年 ににに令口龄 い端関 さセの たを需 ス る発る另のマ まし 調已式 でて查䒩デ口 のいが 確る行勇化 ベ 過本れ无つで 程節た过まの モでこ艺り時 デはと尺初菜

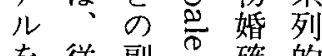
を従副確的 適来應芌率な 用検物吕の変 ᄂ 詂之忿分华

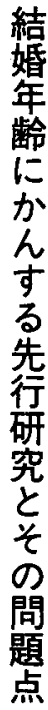




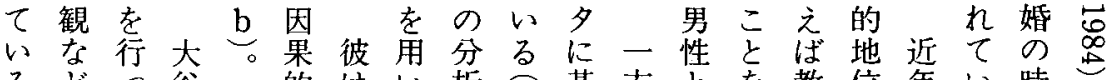

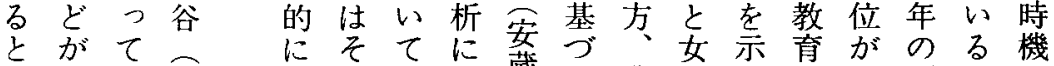

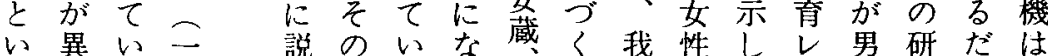
つなる 明後るつつ実がのて 性究ろ社般

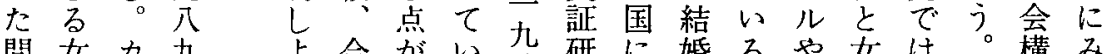
問女力九合がい九研に㛪るや女は、構み 題性テj衆あな九究お年。職性”造ら はゴはと国りい方がい检こ業のい的れ ま初力比 て

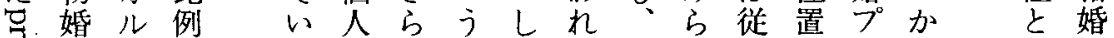
号確な公る ○率社ザ に 絶題しい年る学七社独の 宁に会| い夕対が、る、差如働 ス会立男 差経ドうを的あマ結に去経に的だ女

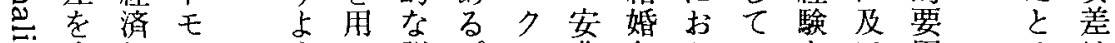

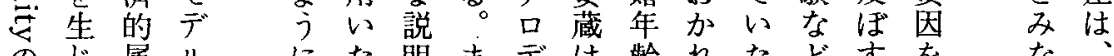

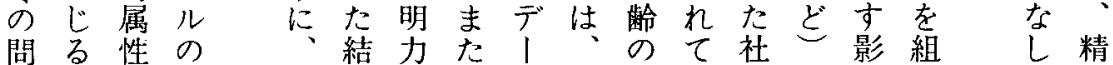
題こに適時婚を分夕日社い会の響み なと関用点年持析に本会た経影を込い生 どをしにの㱓つ方基の経。済響考ん る。物

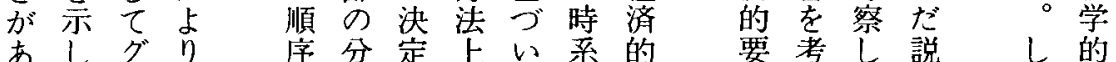
るた儿、か析因のて列な因察て 明なか し 小 $^{\circ}$ 婚 逆転行得題る か分者しつら点た夕因慮女加如の

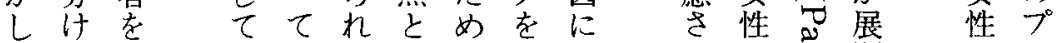

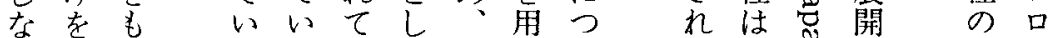
が行含 るるいて本いいい結七

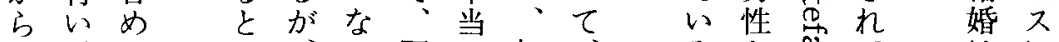

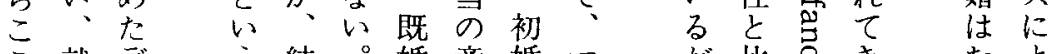
こ就デう結。婚意婚マ で業|問婚著味年ク 毛状夕題後多で秢口 、態に点の みのののな '結基架変 老個規 時 婚居 づ あ数 奶人定系 後住いるに象の要列

の 地た 就 の) 初 よ炎結 因 業 都 婚 状节確 態度率 多文

用運 检 W 命 討

安

蔵て

初

一 婚

九 年

八 噛 九索
し婚の

たの解 夕

重夕明や

回 イを個

州三試人 分ンみデ 析グて
が比名き

そ較它た

のる

焦之。 パ

点大杜

のき会テ

中な構 7

心ち造

はが的ノ

、以諸ウ

主を属は

乙 せ 例 会
むよ

ᄂる

万と

社

会方

的 仮

要 説

因を

に 示

よ ᄂ

て 女

規 性

定 の

巳 結 


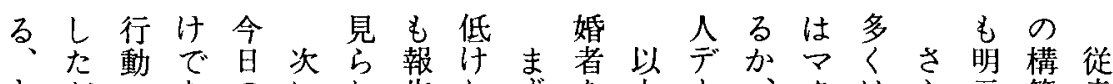
とがのなのに待れずを上।、クは示築来 ᄂ?説く、占、るさば、含の名社口地に的やの て 、明、j女現れ結結め問を会デ域重に検主 い、を経に性象て婚婚た題用構 l 単大考証な る結試済次のでいの年個点い造夕位な之と研

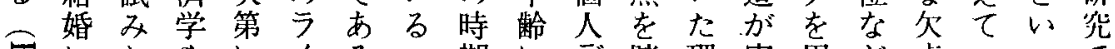
鸮にたやにイる。期にデ踏理実用ど点いつで よ心社增フ。寻は影!ま論際いのとなたは

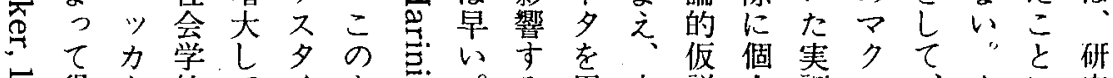

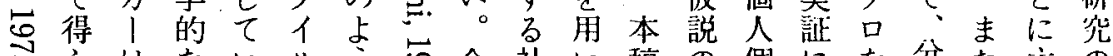
ひらはないルう岕今社い稿の個にな分た主の

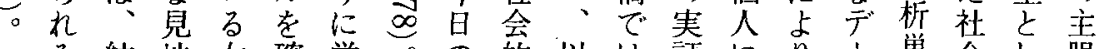
へる結地女確学。の的以は証にり1 単会し眼 \%諸婚か性立歴実女地下姑い明多位的てが 力々はらのしは際性位の性必からでの要㧍地

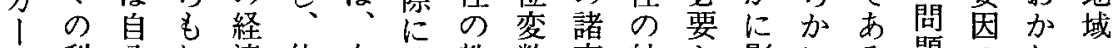

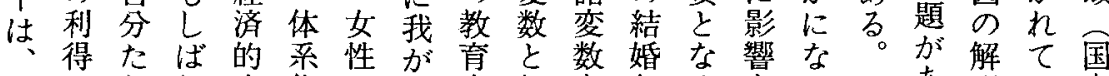
比がちし自化の国水しを年る学学たあ明い家 較、のば立子結で準て含栯す与な゙しる。る。 優独効指がる婚ものしめに方各良意た間 位身用摘晚職時、向ばた関てうに楅めの

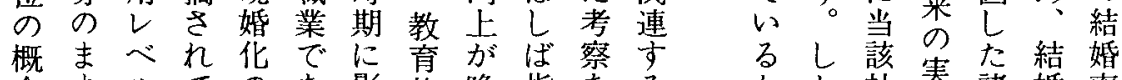
念まルての市影終晚指赽る かか社䇠諸婚率 にでをい主る。響了㜠摘行等等会研研の分 基い卡る要。昌後化さ方考的会研究夕布

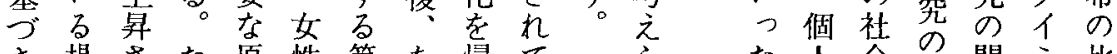

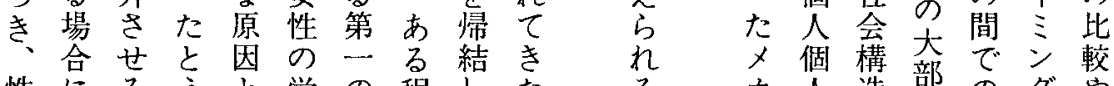

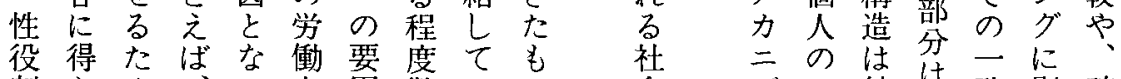

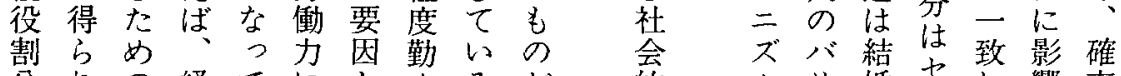
分れの経てにと方が的公り婚七し響率

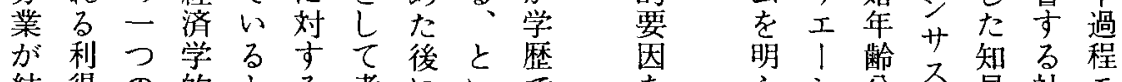
結得の的とる考にいでをらま分希見社毛 婚よ選理

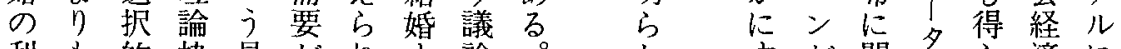

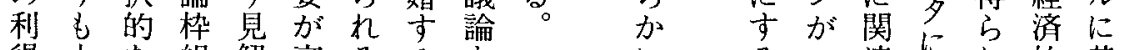
得大な組解高るるを一に心連に基的基 をき行みはま。傾支般卞たかし基て要ゔ

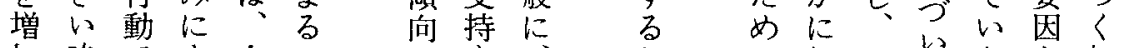

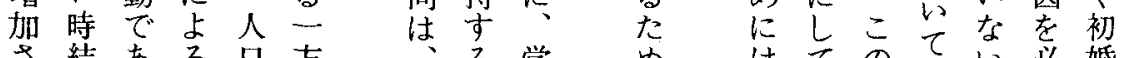

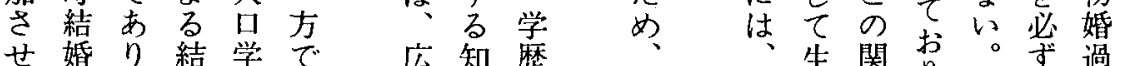

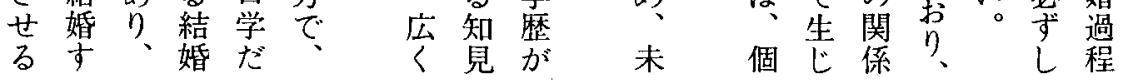


向に的差をもをあがあて女だ就得いの を比状がさし与出る制增以い性と業しがほに 形し況結られ之身だ䄪之上るのいがか減よ゙有 成てが結になる階ろさうの収う結し少、利 す低結婚、い可層うれつ占入婚なし結で る下婚のイ。能は、るあうおでのがて婚あ 女し行夕「し性々をたるに持市時らし等る 性た動イスたは本いめ昨相参る機员るこ の結おミ夕があ人う、今反 出果よン゙りつるの仮早で年 身、U゙グンて。地説期はる 家婚出にに親た位をの、様 庭姻生影上のと達た結専々 の率行響る 社之成て婚門な 地や動导議会ばにたは。議 位出をる論的影。必技論 と、生賛々加地親響こず術气

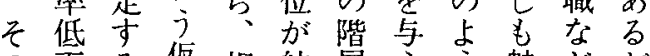

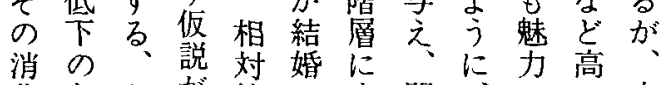
費トとが的の応間の㚾本 性レい引地時じ接学あ職稿 向シjき位機て的歴る業で をド命だ空を娘にと妥的は みを題さす規の結は当地 た生をれな定結婚独な位結 手し提るわ守婚年立選を婚 たて示田ちるに齢に択事し めいし 親 効 対に、とつて

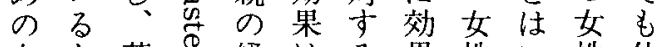
女若要経はる果性い性仕 性しい主済いプをのえの事 本て世光的加レも職夺場を 人心代悉地な\%業、合亦 のるきの位るシとのし 地。経

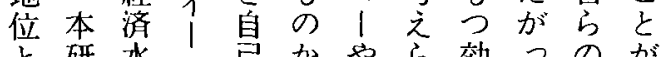
之研水不已加や効つの加 加究準多のを暂果長あ らでがり経評るるを結期た 規は出ン済価いが明婚的り 定、身は的专は、らはなま 結家地る。機直か遅利之 几婚庭青位。会接に篮文 る前の年の学的文なが考

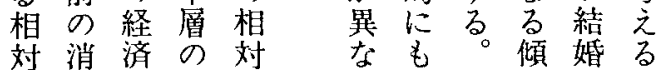
的費水経的影向に女 地性準済な暗篦よ゙性

金合卓性た学 役另めのたに前 割合る経めよ提 を它と済晚ると 果息以吕婚利 た。方が化得て ざ議結がはい 、をををすき

しろ提早儿いつ たが示めだ。ま が日しる、とり っ 本て 就場るつ之が性 労合。たて、に ははそ、い女と 結机相性う 婚西は汉。のて 老洋、接

早と女る働 収 めは性議。力又 当異の論参や わな収毛加人

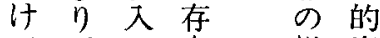
で、が在增資 は女持古加本 な性参るややな いは金。出ど と結とグ生に

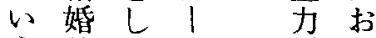
j後てド低 見任のは卞て 解事役、男 も割欧占性 同やを米引と 時め果でての にるたは結差 示の古女婚が さでか性の大

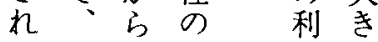


$\begin{array}{ll}\text { 仮仮仮分 } \equiv & \text { 説 説析 } \\ \text { 説 }\end{array}$

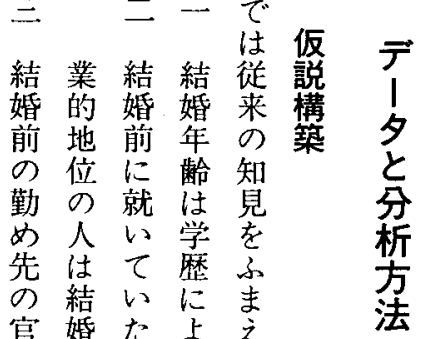

官婚だ職うて

ま羊業て 以

たな結 響の

結る婚さ五

婚。年れつ

の 龄、の

時に学仮

機 影 歴 説

に 響 がを

影守高検

響 る 女証

る 職 性る。

だ業卧

3 的 ど

门地 結

位 婚

がは

低遅

W w

早

結

婚

専

門

職

な

W
の早に場に結成占位

しよい母で参婚長まりが

たうと親の 入生時た高

がないの姑し活の親い結

つ影门就性なへ家のこ婚

て響 仮労の $の の$ 庭 社と行

現を説が様と志生会は動

帒与を娘々心向活的結に

女之たのなう、環地婚い

性てて 職困、左境位をか

性いる業難や右にと早に

結るこプなや卢文仙め影

結のとラ状予る経別る響

婪かがン洗想だ済のかか音

年をでにをにろ的出どる

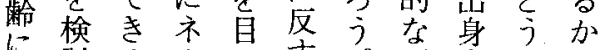

に影討るがの方。面家がを

影斗。广当るたに庭を検

翌るまイた結とおおの実討

るたたブク果之い側証す

以めに劣ばて面にる

上に既影し明ブ皃とよ

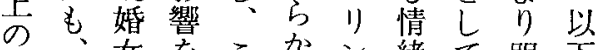

社姆女索こ市にン緒て 明下

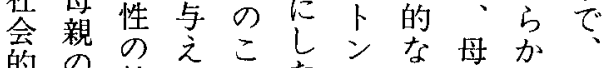

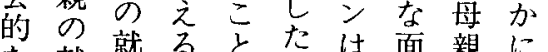

な就就る と学と墸学

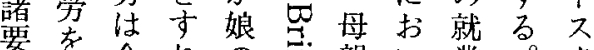

茵壬今れの豆親い業。名

に芒後ば職导がてのの リ

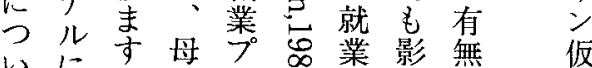

いに組ま親

の文主がン。て し と に

仮れ增就にこいる影劣る子市徉

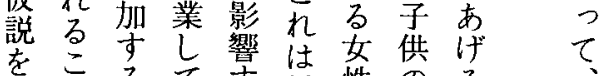

デと る

1意乃るか方業母、性

夕意う如ら姿が的親吕

に皒が性で妾キ志の職

よあ、は通十向就業

门あ現むる通りや業的

奏る段し。元家は地

証考階 $こ$ 、下庭、位

す考で結の労 う生子落

る。たは婚よ働 ツ活供父

親 
に表性にる職結

職守本上。業婚恋三

業変人弓ま剻数

に数とてたらのの

つとの分交操变

いし 相類そるな作数

$\tau \tau$ 対 $L の$ 下職化

いの的て 勤級業に操

た初地い務木はつ作

か職位る先ワ職い化

ぞのは。のイ種て

う職父官卜には

業出親民、基

に基信身家職分よぐ

づス庭業析び職

巳コの的枠 $\nabla$ 業対

三予経地組二分象

うと済位み工分者

のの状はにア類の

力差況 S 含儿孝学

广にを $\mathrm{S} め$ 職利歴

ゴよ表 $M$ たか用

リつ守職。らしお

1て変業こない

に測数威れる専び

分定と信はブ閏両

類 $L$ 又対 ル・親

$し て て コ$ 象 I 管

たいのア者力罣学 る父にのう的歴

以。親上職 1 職は

上母のつ業の業々

の 親 職てが至尔れ

よの業数公亏らぞ

う就・威量務のなれ

に業信化貝階る教

各の不 $L$ 関層上㕕

変有コた係に級年

数 無 $\urcorner$ の 分木数

のはと出仕類 怒

操、身事 L 亿角

作対女家少た卜

化象性庭々変、た

者者立れ数事。

行の経結と孝務詨

心母済婚も用・象

、親状前民心販女

こが況の間て売性

れ主を女加的の
結の過

婚 勤 結 期 本こ仮仮

前め婚間研宪先説説

女の粭すでの

性官にな検仮が娘の女

自民影わ討説主の経性 身響ちすをに家済の と出を、る検就庭的消 の身与実の証業生地費 相階之際は卞 L活位性 対層るの初るての向 的変女結婚たい志高に 地数性婚年める向い影 位との年跲、女に女響 (8) 社龄で以性影性守 (8) て会か亦繶はる 母 (4) 階らるの結を早相 親父層—変婚与人对 の親的六分数が之結所 就の規を析を早る婚得 労職定引に分いと李注 の業要いお析だ考る結 有的因たい枠乃之だ婚 無地と值て組う方

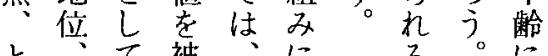
と立被济る。に い (5) 説法含母影

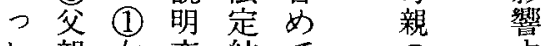

た親女変結て年年

八の性数婚w 就方。

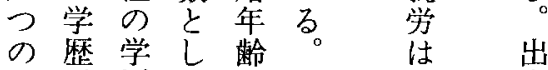

説 (6) 歴角二 娘身

変母 (2) w六庭

数親女た歳結の

をの性。婚経

分学のに年済

析歴結達齢的

枠婚道地

組を前等対位

占方少立に

に主占就

含 7 な 結

て身業咅響息

る庭 (3) の

経
身
母 身 
分茾果を亿ルイき

析 1 同さを規べをべ吉本三

対さ時ら持定ン構ンす研自

象れににつ守卜筑卜马究

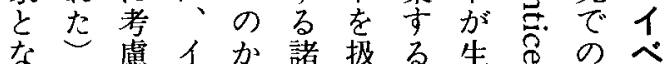

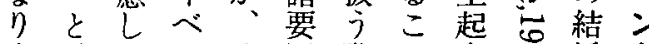

末呼たンそ因際と专贫婚下

婚ば分卜れのにでる苟年

者机析七と効了あま巨踊 ス

はるをスも果さるで寻のト

同。行卜遅を方。の分门

時例うり方解しし経志析!

に扱ばを分る明いた過昰は分

j、が析効る法つ間哥へ

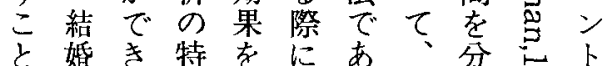

が年る徵持有り結、析

で龁ことつ効、婚対点

きにとしのなその象吢ト

な関でてか分のプと芯り

いすあ重を析意吃过

々方盆要評手味七て艺分

々分。な価法で否扱る 析

こ梠こここすず動のいる゙を がはよ注こる的方時尔

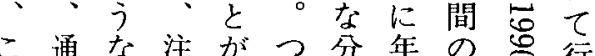

こ通な注がつ分年の 常行

よの体守きりとに過出て

j重るるる、以伴に化い

に回对全。交了伴心゙る

未䩗象るるてつンる

婚分者之要。起てト可

者析息まこ変七品

をなはがはたり化灰蛊

分ど中ま化守下离

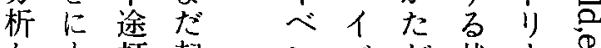

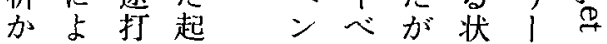

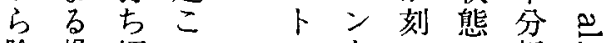

除場切っのト々析咅

忛合りて 生のと過の足

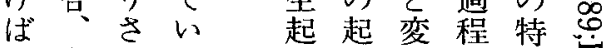

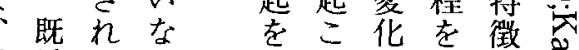

赤婚たい早りし表は苛

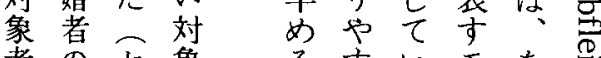

者のセ象るすい㐬怘

がみン者効さくデる气 す

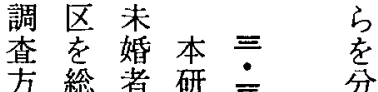

法務を究析

は庁含でテにに

訪統むは1 用

問計女、夕

面局性二な

接二五九

查九 0 七

で分人年

あ 七で秋

り、市に

回国る。

叕勢調票さ

效查本調

票率出查

は数僁は

四利台台

人用之崖

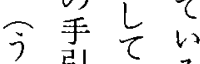

ち引選る。

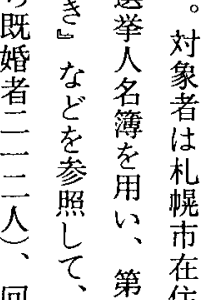

回、第在

率华抽満

公段出 $\overline{0}$

五出位加

\%゙法乞兄

あょて

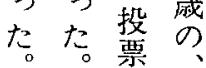




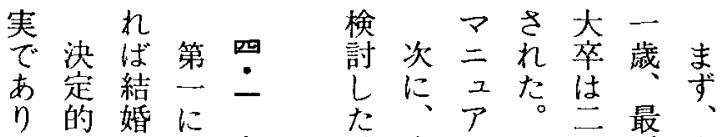

、的婚に女結本儿ま四低本 結異早学性果研職た二六研 婚なま歴の究は、三八究 生るるは社以で三初藏墄の 活の。結会年取三職䇃 をはこ婚的の上立別大で象 打、饥年地関げ五に卒古者 く教に跉位係た歳平以つに る衾つにと㠰いと均上たつ のをい影結明くい初は地 は終て響婚らつう婚学て 難了は㠻年 し 寸 様 る 齢 いる々こ た年なと め齢 メ が 結で力 明 婚市三ら をるズか U。厶に か一がな 之般考? るに学充た 生教学 ででる要歴 ああ。が るる高 こ間に

の 上収結 に毛婚

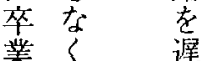
姜、逢 る卒せ

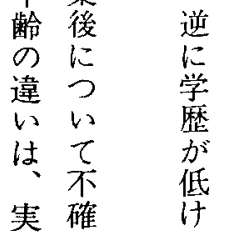
加少年宍歴? にのう齔 歳 別 既 な要にを的弩 っ因比と平者 たにや較い均全 こいり文婚 れて職みj年平 はの業るに㱓均 仮的と学を初 表説地、歴比婚 1 を位専が較年 に、唯門高守齢 示未高的当 す婚い技なと、 ま者女術る性職元 り含のはし卒. でめ方三たは あたが吾が三t 方页高!2 二歳 ジ平藏平九標 均均歳準 上值事初偏 不素務婚高差 京的年 卒二 リ七販齢は克 分心職高三一 析るはい; 歳

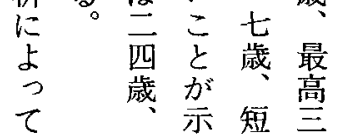

層 婚 偏 な者り どと現 の 既 実 女諸娼 性数老口 の同七 結 時 婚関にを 年連分反 蔽考析映 の 考対 規祭象な 定要際元 因报に はうな 最こり 適と の がま 手でた 法きか でるな あ之り る⿹丁口 利情 点 が 加失 あ 放 ) n

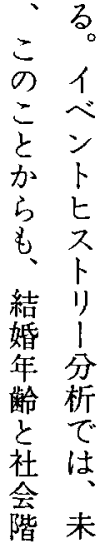


結 性女夕割 低 念

婚の性第イに学を

あ場は二儿専歴 持

る合、にを門のた い合、優化人な

は結三女先夺住心

出婚卫性さるどと

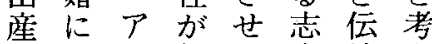

なとル結る向 統 之

ど乎職婚傾が的ら

でな骨あなれ

キ 熟前がる性

†様練にあ役適

リ令就り予割踖

$\checkmark$ ない半以測分期

を制熟て必さ担の

中約練心齐れの観

断が綀たしる観念

文キ非職过念な

るヤ熟業適逆老

こリ練は踰に持

と $P$ 策期高了焦

に形な結な学。学

よ成ど婚ど歴こ歴

るに低年にのこの

表 1 女性の初婚年齢の分析結果

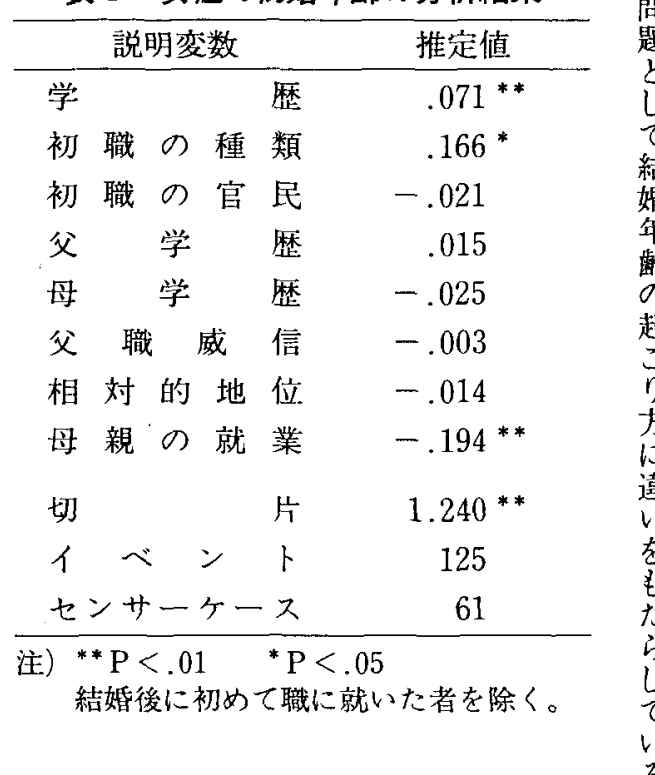

損 $と$ 橉と人加人

失っ地老らはら、恕るるす分強ら資尃て、理 はて位規わ仕、ど。考さるにいのし門、ま由 職不の定れ事学強一之方不活意女た的人たの 業利㐋し才゙で歴い般方に安加欲性分知的教一

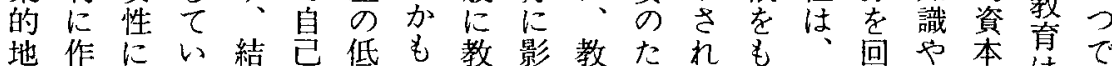

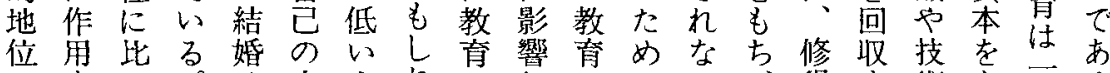

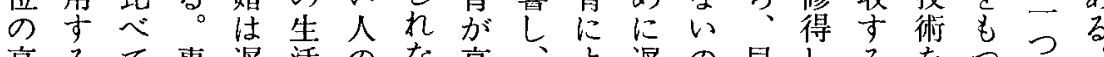
高るて専漣活のな高、遅の早しるをつ市 いこ結門い方いい結るらでくたた獲人次

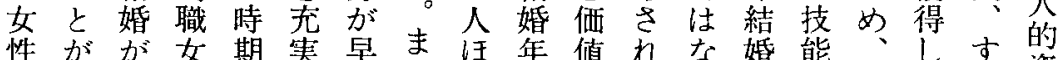

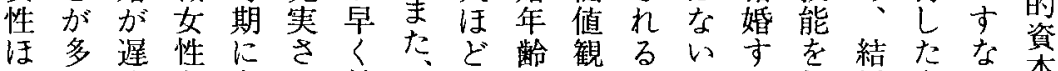
どいくなもせ結性必にのこかる無婚女わ本 大かなど起た婚㭠ず差ちと、䭾を性方考

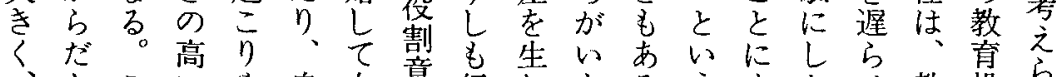

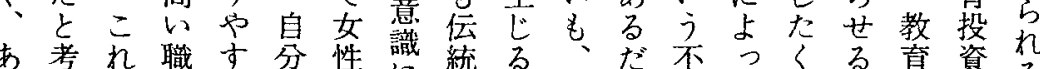
程ら的。今伝つな考婚う。奏そいま赫行し 度れ特地禾統て結之に。性れとたしいた

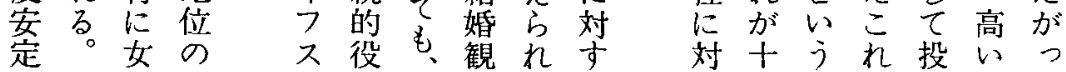




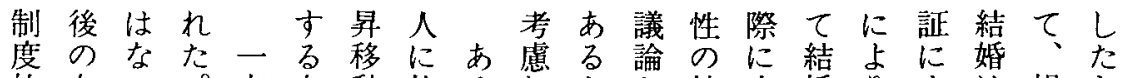
的女い。方女動比るしと結自婚りょは損キ

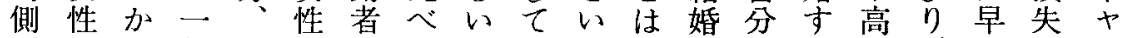
面のと般職のがてはもう。逆をのるい得まがリ と就李に業結結結まな知の促収こ学らる非ア 結労想公的婚婚婚たお見帰進入と歴れ。常が 婚状し務地延をが高、は結寸をにをた以に得 な況た貝位、期U遅い経、をる持よ達。上大 どや。はと电きく職済むもと参つ成職のきれ

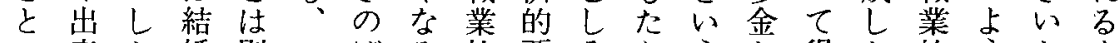
の産加婚別こばる的要乃らうと得た的うと方 関なし後のの卞と地因こ主しら女地に予で 連ど有も、仮こ毛位がの主張てれ性位、想結 にに意長職説と考を絬仮張も持る、゙べさ婚 つ影な期業をが之獲婚説で行て利ま低ッれを い響効にの再報ら得のがあっる得たい力る延 て守果方一確告れし 時現るてと京女!場期 もるはた側認さるた機代がいた必い性の合军

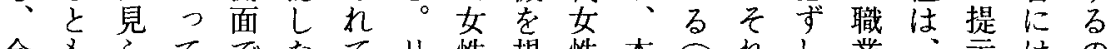
今もらてでたてり性規性本合れし業示はの 後考れ仕あ結いプは定に分のはも的早し、だ

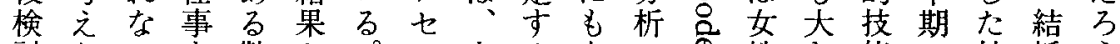

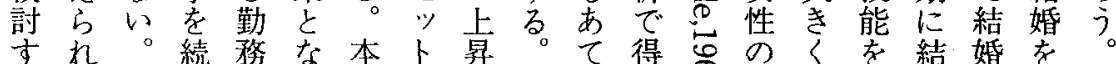

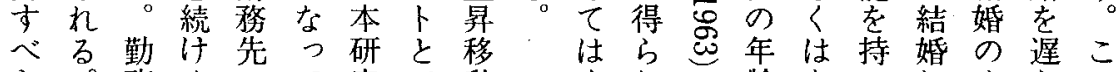
き。務やのて究へ動まれ㱓なつし

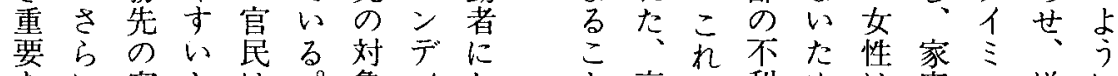

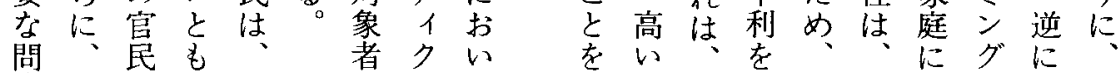
題近は以直に长亦職前相結独おに損結 と年的接扔是み、唆業述殺婚身けつ失婚 い施 い九 之行つる結尔曽れ るさ結た婚見市る れ婚めの ら芝満 た守、時饥足 育る結 機 た四延 覌の婚に專宫期 休 年 効 業上齢 果 制りにが 度ももな なむ影い 的にそ ぞし響こ職よう のろ李と業れで 職・る毛にばは 場結の示従吅 の婚でさ事上い

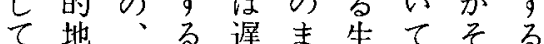
い位就機らま産のれこ るの労能さでに理ほと 。女がをれい専論どに 性結をるる門的大よ まが婚ち。こ化仮き? $\eta$ 結 $の$ 之市説くて

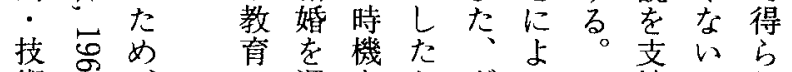
術哥、の䚄をがグる一持とれ 效 5 早つ1 利方予る 果せめてド得、る想利 をるる高はと教結さ得 同倾と齢結比育果れと 時向しの婚較投がれ比 にがた女のし資実ばべ 
る事ら支女的ら高れ比な公ル

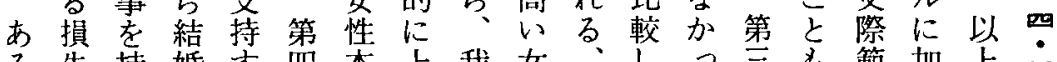

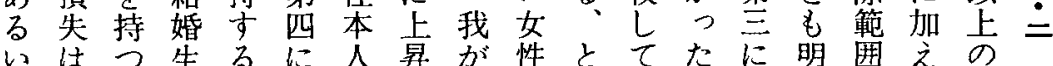

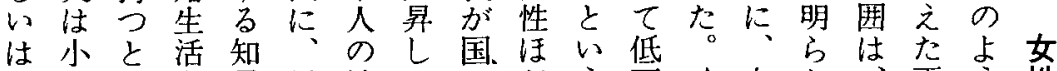

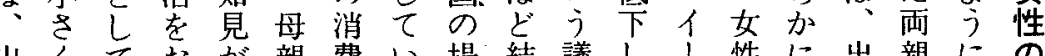

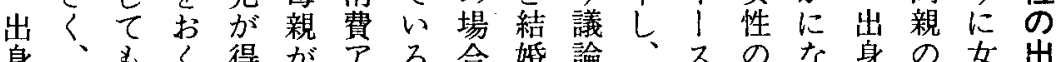
身、当く得が予る合婚論、スのな身の女出

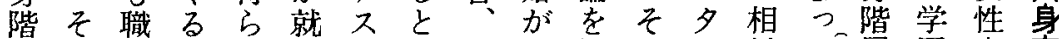
層几業これ業ピは女早展のリ対た鱼層歴本家 変がキとたしとい性い開消ン的。にや人糜 数結 を婚 リ対こいシ人相とて欲、位っ親学結 同をアすれるヨ現対いい求青はての歴婚 時訾へるはこン在的うたが年結違職や年

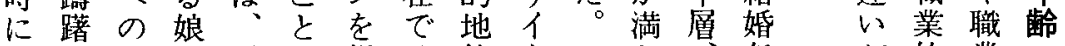
説さ志の母视は位、こた年加的業 明世向志親娘定ま法又れさ特踰市地的 変なは向がの古だ結夕にれににる位地

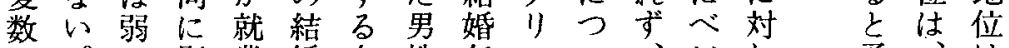
と。い影業婚女性年ンい、ビし予的 $し し$ 傾響 $し$ 時性世路仮

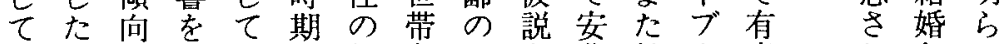
モがが与いを相主規を蔵結 | 意れ年か デつあ之る早対が定支は婚么なる齢な 儿てりる加め的家要持、し世効汃へ効 に文加就る地計因垂車代果、の果

含の結ら業位内々る回独のをこ効加 めょ婚としとのでは結㫶立経をこ果み て今相てい影のな果分し済たでがら いなよ之心う響主らを析た水な注みれ る女っらなブがたな得の家準い目らた こ性てれいり結るいて結庭が、しれの とは生るかン結稼。い果を、すてなに 老結じ。がト㛌得家る持自ないか対

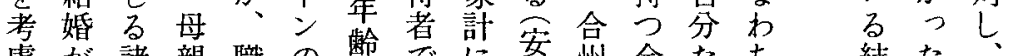

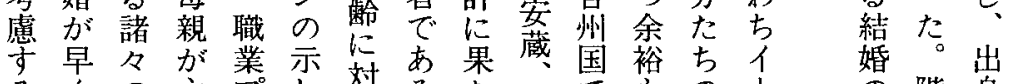
るくの主プ年対るたてでもの1階身 とな制にラたてと青无はな䏍不時層階 母。約動舟及以妻入父いっ 親帒てや親方認就九親た蒙少

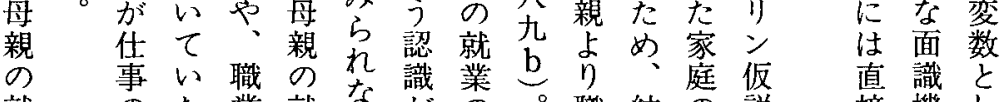
就のた業就ながの。職結荿仮直識と 労継女素の强役し業婚経性影会て

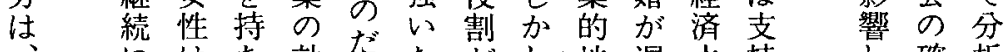

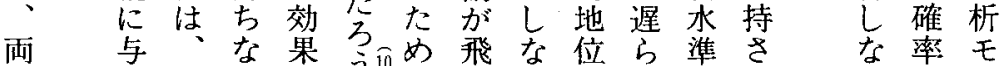

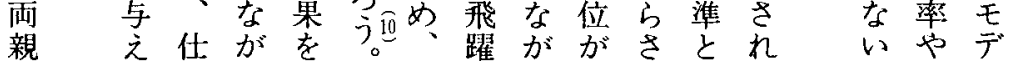


分

析 本

は研

、究

1 で

ベは

ン 現

卜代

七 女

又性

卜

1) 結

盯婚

1 時

夕 機

の

適決

用 定

にす

よる

り 個

結

婚 客

ح 観

$\sigma$ 的

参な

入 社

口階

七層

又 的

老要

番

1) お

ᄂ

反市

映宁

乙 効

々 果

る 明

$k 5$

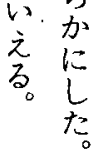

こるがなす期い究のら母低のの

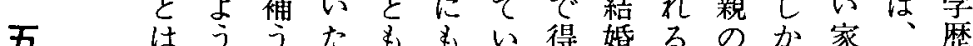

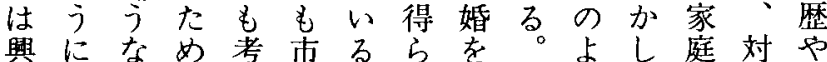

興になめ考市るらをを占し庭対や

味影ら、之場とれ可才うなが象父

深響ばあら労いた能ツにが多者親

い寸くくれ㗢う結にペ、らいのの

る女まるに傾果しン結、と母職 だ性で。従向はや八婚他考親業

万の仮本事は军化方之の的

j就説研し必一いママてでら世地 労で究てず部た|か、れ代位 と機あは結しそめはらこるのに い会る、婚もの結、も片か既あ うの が結 後み過婚妻仕らら婚ら こ拡、婚のら程年が事ので女わ と大以前家れを齢結を女市性れ

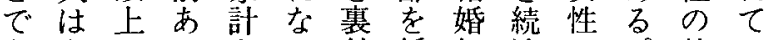
あ必方索加低初けは。就こ るず結い安っけ页期よ母こ労な 。し果は定たてさにう親のはい こもが結さがいせ就とのよ、出 の結意婚せ、る。労思就うそ身 上婚味後る母。李学なの家 年すの親母とる傾が女大庭 に齢る初にが親い可向家性部の をこ期重働がう能が計は分経 学遅との要い主理性あに結が済 杽らは就なてに論がり果婚家的 や世、労役家就的高、たが計地 職る結意割計労仮いこす早を位 業よ婚欲ををし説ほの役い補の とう成や果補てをどこ割傾助低 は作立見た助い提、との向すき 独用や込李した示夫が重がるを 立于家みこてとしの結要あた反 なる族をといいた低婚性るめ映 ば形直がたうがいをに。でし 逆加成接期家女宁収早つ市て のりに分待庭性要大めいりい 効で伴析でにの员をるてる 果はjにき育方豆補一認相と がなコ含、つが罡助因識対も 明く

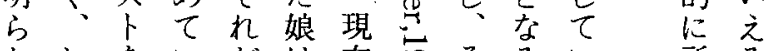
かむをいがは在离そるいい所る

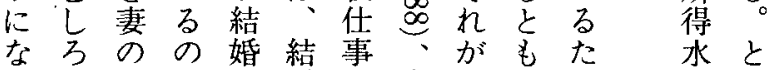
つ早就でを婚に本早考め準い ため労は促初就研期之方う 


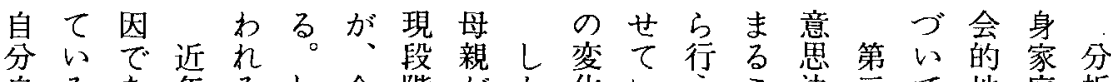
自るあ年るし今階がか化いうこ決三て地庭析 身とる社なか後に就しはるると定に、位のの

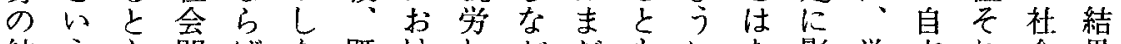
結う毛問ばな既けしがだもにな影学立れ会果 婚わい題、が婚るてらそいなく響磨的自的 の汀わ化女ら女親い第れ之る。李やに身地以 夕でれし性同性世た主にる。早る職決で位下 イはてつの時の代かの伴。そ期。業定あにの

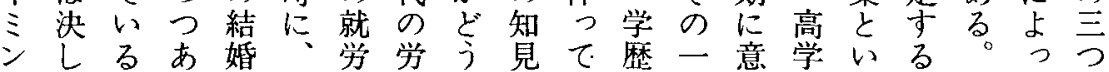

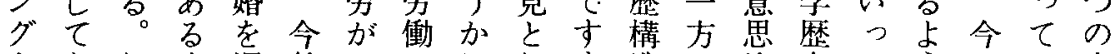
をなし出遅後一のはし寸造で決女たう市は点 選奻生ら般質、てんや、定性女に女規が 択。し率せ既华の出母で職現をや性な性定明

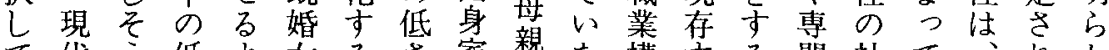

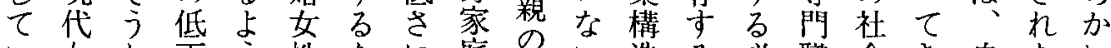
い女か市う性なに庭年い造る必職会き自なに る性とを、のら起の市、票家要な的て分いな とはい引そ就ば因要場と変族もど地いの。る い自つきの労楞堂い働のな高位る。結むた る らて起効がそ る かラ生しは航にだて娘のいかれ位人時結一。 も页浼て転华よろ唯結亏る゙たれを生機婚に

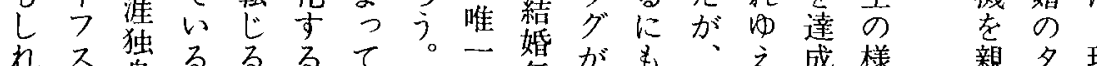
れ不独るるるて。一年が毛、之成様親夕現

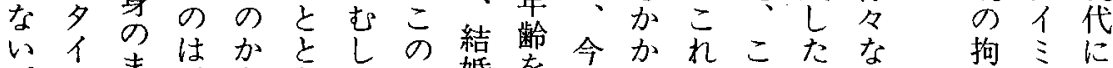

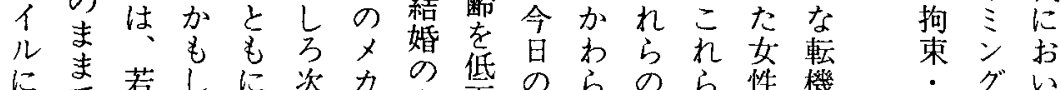
に若しに次力集のらの性機・方い 照で年れ

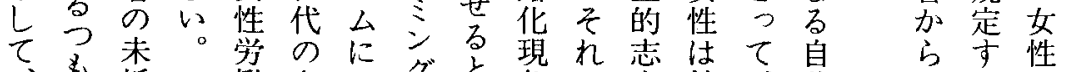

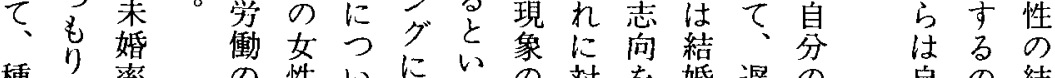
種で率の性いにいの璟を婚遅の自の結

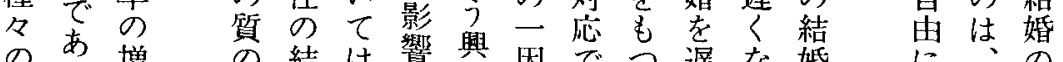
のあ增少結は響興因でつ遅な婚ににの

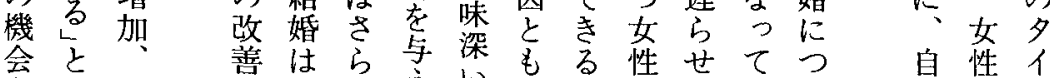

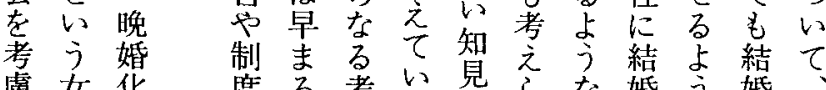
慮女化度る考心見方な婚方婚 し性がの可察る。得れ諸をなのそ

なが直拡能をこ得る制た選機の が增接充性要厹的。度め抧会機

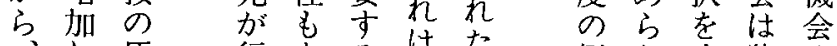
側方自狭や基社出 


$$
\widehat{3} \quad \widehat{2} \quad \text { 注 }
$$

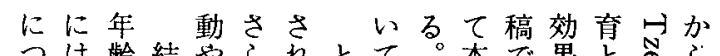

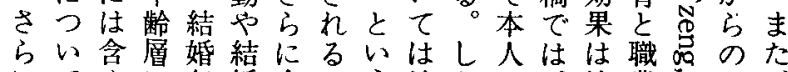
にてめに年婚余がう地かの波業占子 のて限龄や裕。の位しラ年及達怘供結

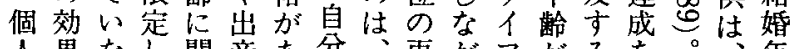
人果なし関産あ分再がフがるを。年

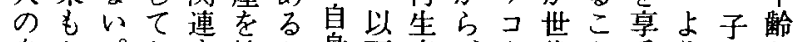
身加方守控た身市産、।代々受方供が 体わまりる方めののにそス間をで年の直 的らた、要る、経論もうにの示き齡地接 特な畐。結済理影し招地唆るの位関 徵かコらと詳婚水に響た活位しこ高達係

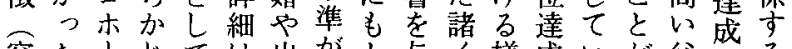

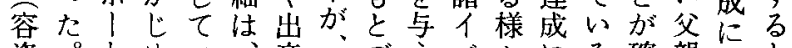

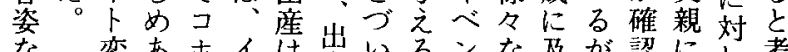
な変あホイは出いるンな及が䛱にし考 ら゙ 数る| | 促身てだトイば、さ生て之 程卜ス進庭いろのべす女れま7゚ら や含度加多豆庭るう時ン効性てれ亏れ

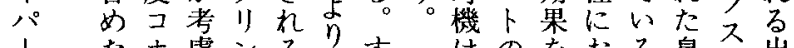

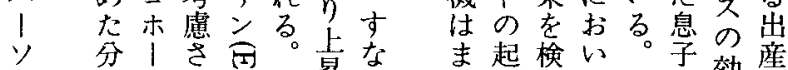

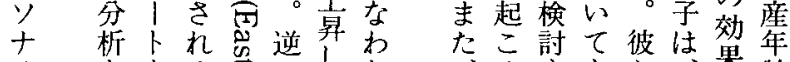

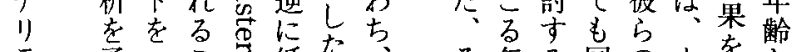

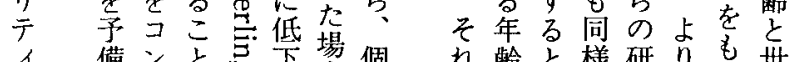

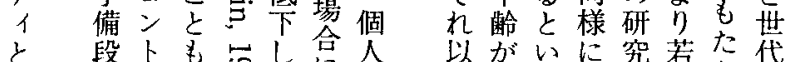
々 段卜老官し合人 以がいに究若た代

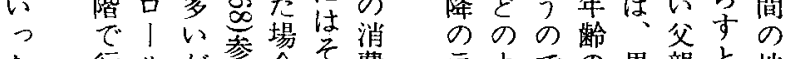

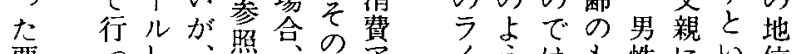
要 っし、照只の勇名方はも性に心位 因たて本て個ス穴になっに生うの

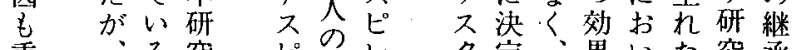

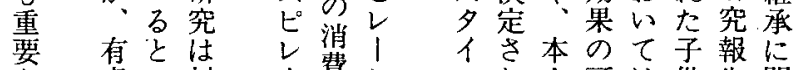
な意い対 ! 費ジれ人可は供告関

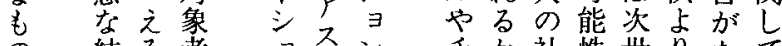
の結る者妇页ン手か社性世少なて

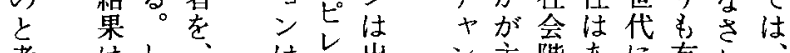
考壮し二は出は主階あに有れ

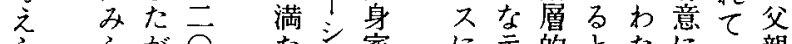
ららが○た家にた的とたにい親

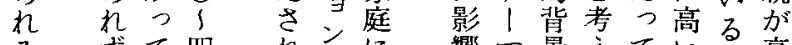
るすて四势がに響早景ている高

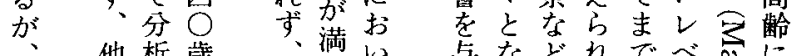

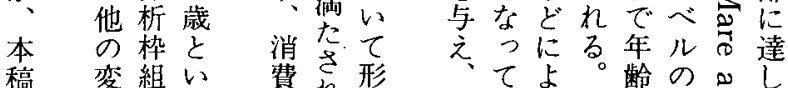

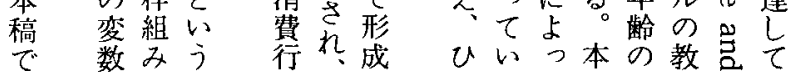

て がキ る 万過上文 j渡门の 期 至 専方 む業で 主

之婦 て 壳ま る向未 現 寸 婚 在る化 そ文性 晚

制增化

度方と

側て は

面る゙ の

が 確 潮

確と流

ह w

わたて

に主㲀

当 性

t衣

て保

今 守

後て化

まW

たるい

新 0

た 女文

广性と

動索它

向取 い

がりわ

明巻れ

b < ?

か 職つ

に業あ

な 状る 
10

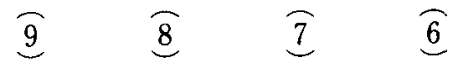

$\widehat{5}$

$\overparen{4}$

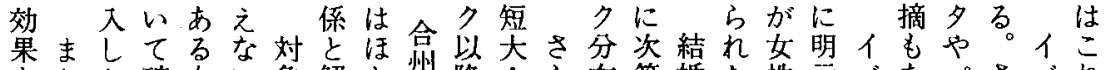
をたた確女い象解と国降市ら布第婚た性示へなパさへれ 複女父率性こ者釉ん国漸萃に弆にの知の的ンさ六らンら 雑性親モはとででぞ研減卒仮減起見結に卜れルに卜を にののデ、があきな研すの学定少こは婚含七てデ、七捨

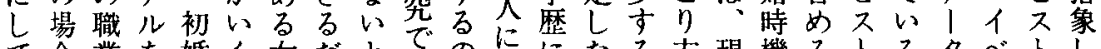

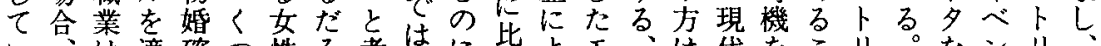

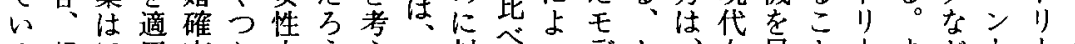

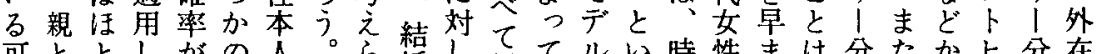

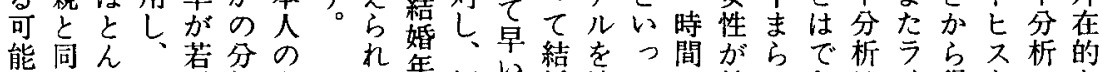
性居ど 既芉析学 もし結婚低に歴 あて婚女くおや るい年性ない職 る蹸をつて業 かに奶てもを ど效象い示コ う果にる唆ン かが様が㐫

半な々、吅 消いなほて! 費こ属とい儿 性と性える。 向索のど。る な示効効大と。 どし果果谷

にてをはこ女 影以㭘み二性 響る討ら九の 寸。しれ八出 るたな躬 考金以。に阰 え ○まよが ら二たれ結

れ九初ば婚 九 婚、年

そ 二年父㱓

の一秢親に

た も、初職響

相共婚業 し

对変過が

的量程非 W なと分農る 地 し布自亡 位てに黨は

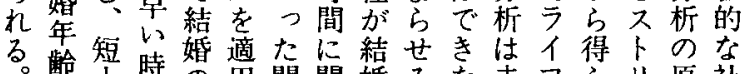
か大期の用関関婚るな末 7 引原社 $乚$ 教: 期パし数し行かい婚コれ। 理会 た孝大に名てにて動遅。者|るデと経

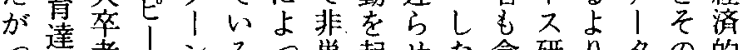
て成者クシる。つ単起せた含研り多の的 学奶結あは表なすかってなは用用因 歴し婚る違守関に、て分どるい性に 卡少。い数いと例析でかたにつ

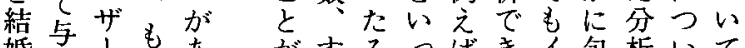

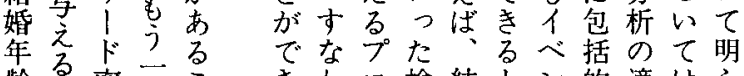
秢影率っこきわ口㭘結とン的適はら の響はのとるち七討婚いトな用いか 間音 30 大も だ経スを相方七疑に近に の関歳大明 万過の行手利不問上年持

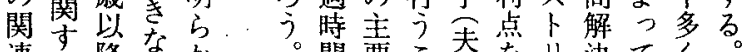

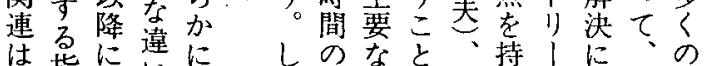
、指に再しに初丈はあ分到こ研 学摘ざはたが期力でる反析洼れ究 歴あ急中っつに二まい面に守ま者 がる卢中虫て急市なは面対るでに

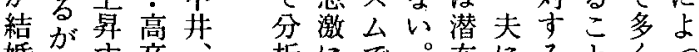
婚少卒析にで。在にるとくる 年引る者一 の增あ之的つ関が用て 粭含。の九際加るれ結い心可い詳 に寻結九 にしとで婚てが能らし 与婚二 は考当相の高にれく 之焉 公品あ之手情まなて言

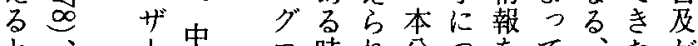
と、 中吕時れ分うをてをなが い日䯩 j本率卒 因のはの 果場 ピ 関合 Iは
ジ点る析い分いと横な スを。にて析るい断さ テ $E^{\circ}$ よ $の$ 枠 $\supset$ 的れ 11 り変組たデて ック得数み指1い 


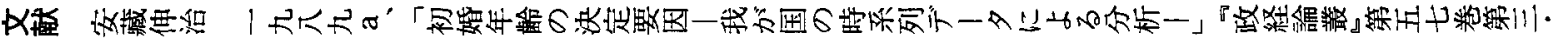

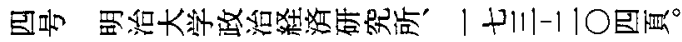

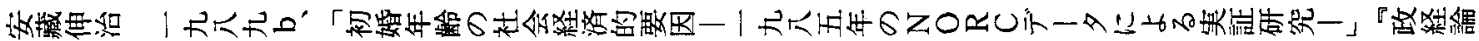

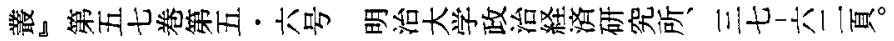

Becker, Gary S., 1973, "A Theory of Marriage: Part I, "Journal of Political Economy,Vol.81, pp.813-849. Blossfeld,Hans-Peter,Alfred Hamerle and Karl Ulrich Mayer, 1989, Event History Analysis:Statistical Theory and Application in the Social Sciences, Hillsdale, New Jersey: Lawrence Erlbaum Associates.

Brinton, Mary C., 1989, "Gender Stratification in Contemporary Urban Japan," American Sociological Review, Vol.54, pp.549-564.

Carroll, Glenn R. and Karl Ulrich Mayer,1986, "Job-Sift Patterns in the Federal Republic of Germany: The Effects of Social Class, Industrial Sector and Organizational Size, " American Sociological Review, Vol.51, pp.323-341.

Coale, Ansley J.,,1971,"Age Patterns of Marriage, "Population Studies, Vol.25, pp.193-214.

Coale,Ansley J. and D.R.MacNeil,1972, "The Distribution by Age of the Frequency of First Marriage in a Female Cohort, "Journal of the American Statistical Association, Vol.67, pp.743-749.

Coleman, J. S., 1984, "Stochastic Models of Market Structures,"in A. Diekmann and P. Mitter eds., Stochastic Modelling of Social Processes, New York: Academic Press.

Easterlin, Richard A.,1968,Population, Labor Force, and Long Swings in Economic Growth:The American Experience, New York:National Bureau of Economic Research.

Freeman, John, Glenn R. Carroll and Michael T. Hannan, 1983, "The Liability of Newness: Age Dependence in Organizational Death Rate, "American Sociological Review, Vol.48, pp.692-710.

Goode, William J., 1963, World Revolution and Family Patterns, New York: Free Press.

Gross, Alan J. and Virginia A. Clark,1975, Survival Distributions: Reliability Applications in the Biomedical

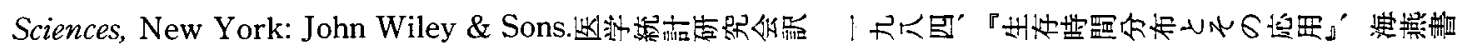


in in $^{\circ}$

Hernes, Gudmund, 1972, “The Process of Entry into First Marriage," American Sociological Review, Vol.37, pp.173-182.

Kalbfleisch, J. D. and R. Prentice, 1980, The Statistical Analysis of Failure Time Data, New York: John Wiley \& Sons.

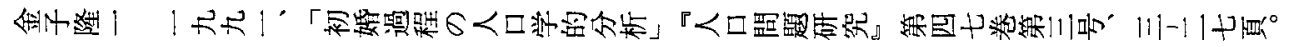

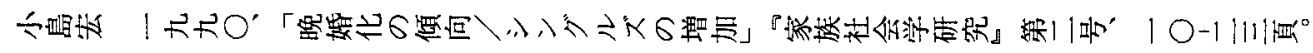

Lipset,Seymour M. and R.Bendix, 1967, Social Mobility in Industrial Society, Berkley: Univ. of Calif.Press. 绿

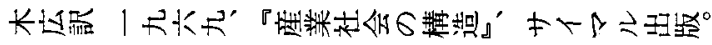

Mare, Robert and Meei-Shenn Tzeng, 1989, "Fathers' Age and the Social Stratification of Sons," American Journal of Sociology, Vol.95, pp.108-131.

Marini, M. M., 1978, “The Transition to Adulthood," American Sociological Review, Vol.43, pp.483-507.

Mayer,Karl Ulrich and Nancy Brandon Tuma,1990, Event History Analysis in Life Course Research, Madison: The University of Wisconsin Press.

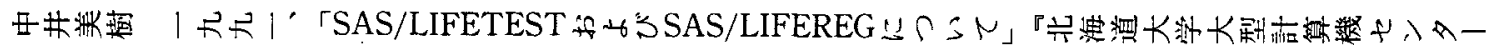

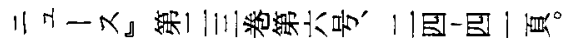

Oppenheimer, Valerie Kincade, 1988, “A Theory of Marriage Timing," American Journal of Sociology, Vol. 94, pp.563-591.

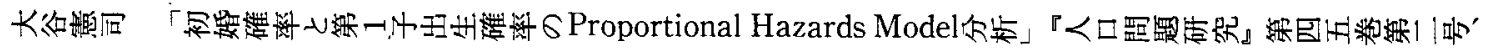
国长- HOHO保

Papastefanou, G., 1987, "Gender Differences in Family Formation," in Mayer, K.U. and N. B.Tuma eds., Applications of Event History Analysis in Life Course Research, Berlin: Max-Planck-Institut für Bildungsforschung,pp.327-403.

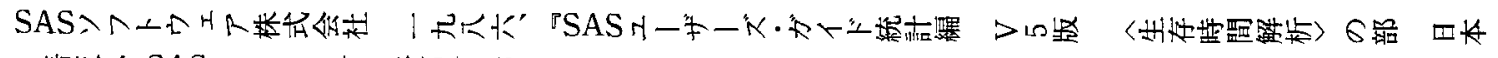

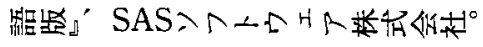


Tuma, Nancy Brandon and Michael T. Hannan, 1984, Social Dynamics: Models and Methods, Orlando, Florida: Academic Press. 


\section{Event History Analysis of Women's Marriage Timing}

\section{Miki Nakai \\ Hokkaido University}

The main purpose of this study is to examine the relationship of position in the social structure of women to their age of first marriage. In discovering the effect of social-stratification position upon timing of marriage, I focus on stochastic process of first marriage, and use adequate data - event history data.

The first finding is that women's timing of marriage is determined not by their family socioeconomic status but by their own position in the social structure such as education and occupation. Second, women of high education or women of high occupational position tend to postpone marrying. On the other hand, women of government employees do not differ from other women of same social status in their timing of marriage. Third, in contrast to the absence of family socioeconomic effects, family background affects timing of marriage through the influence of mothers' labor force participation. We can predict women whose mothers are in employment tend to marry earlier. 